\title{
The Pinochet Judgment: NeW ACCOUNTABILITY FOR OLD DICTATORS
}

\author{
Sarah L Murphy*
}

This article analyses the groundbreaking 1999 judgment of the House of Lords on the question of the extradition of Pinochet from the United Kingdom to Spain for crimes committed during his time as Head of State of Chile. It examines the two main components of the judgment: that Pinochet's status as former Head of State of Chile did not allow him to benefit from sovereign immunity for acts of torture committed during his reign; and that he could be extradited to Spain for acts of torture committed after 1989, when the United Kingdom codified its obligations under the Torture Convention. It supports the conclusion that the laws against torture override the immunity of former Heads of State, and suggests that the reasoning could be extended to apply to other crimes against humanity, and where the accused is an incumbent Head of State. On the question of extradition, it argues that the Law Lords had several avenues open under which Pinochet could have been extradited to face all counts of torture. It concludes with an analysis of the New Zealand legislation and case law on sovereign immunity, the prosecution of crimes against humanity, and extradition, and suggests several law reforms to bring New Zealand legislation in line with evolving international obligations to prosecute or extradite the perpetrators of crimes against humanity.

$\dagger \quad$ This article was accepted for publication in 2000. In September 2000, the International Crimes and International Criminal Court Act 2000 was passed. The Act removes many of the hurdles that existed at the time of the Pinochet proceedings to prosecuting crimes against humanity in New Zealand. It confers universal jurisdiction on the New Zealand courts to try genocide (section 9) and crimes against humanity (section 10). Both crimes are afforded a limited period o retrospectivity: crimes of genocide committed after March 1979, and crimes against humanity committed after January 1991 may be tried by the New Zealand Courts.

* Senior Legal Adviser in the Public Law Group of the Ministry of Justice. The article was completed as part of the LLM requirements in 1999 at Victoria University of Wellington. The views expressed in this article are personal to the author. The views expressed in the article are personal to the author. 
In future those who commit atrocities against civilian populations must expect to be called to account if fundamental human rights are properly to be protected. In this context, the exalted rank of the accused can afford no defence.

Lord Millet.

\section{INTRODUCTION}

Late in 1998, an elderly foreign visitor was arrested in a hospital in London. The visitor was Chile's former Head of State, Senator Augusto Pinochet. Spain had asked for his extradition from Britain for crimes against humanity. The arrest marked the beginning of one of the century's most important and complex judicial processes.

This article analyses the landmark second judgment of the House of Lords. ${ }^{1}$ The decision was that Pinochet was not immune from the charges of torture, but could be extradited only for torture committed after 1988, when Britain introduced a statutory crime of extraterritorial torture.

The case represents graphically the collision between fundamentally incompatible concepts, the universal liability of individuals for fundamental human rights abuses and the sanctity of state and Head of State sovereignty. The decision will help to confirm the supremacy of human rights for the new millennium, but it also demonstrates the need to ensure that the protection of international legal human rights norms is not impeded by statu tory technicalities.

The two hundred and one page judgment of the House of Lords is of such complexity that even its authors concede that it is obscure. ${ }^{2}$ This paper will endeavour to make sense of that obscurity, and analyse the likely effect of the judgment on the domestic prosecution of crimes against humanity.

Part I of this article briefly sets out the factual background to the case, providing the context and basis for international intervention. It outlines the abuses that occurred under Pinochet's regime, and the past failure of Chile to take serious steps to punish the abusers.

Part II summarises the second House of Lords decision and examines its two main components: sovereign immunity and extradition. On sovereign immunity, the paper argues

$1 \quad R v$ Bow Street Stipendiary Magistrate and ors ex p Pinochet Urgarte (No 3) [1999] 2 WLR 827 (HL) [Pinochet No 3].

2 Joshua Rosenberg "The Pinochet Case and Cameras in Court" [1999] PL 178, 183. 
that, despite applying orthodox legal concepts, the Law Lords reached a groundbreaking conclusion that could facilitate the prosecution of former Heads of State for any crime against humanity. It suggests that the same reasoning could be applied to prosecute sitting Heads of State. On the extradition question, the paper suggests that there is a duty to punish crimes against humanity, and that the Law Lords' interpretation of the Extradition Act 1989 (UK) was unduly strict. It discusses three alternative approaches under which Pinochet could have been extradited to face charges on all counts of torture.

Part III reviews the New Zealand common law and statutory framework on sovereign immunity, crimes against humanity, and extradition.

\section{BACKGROUND}

\section{A Pinochet's Coup}

General Pinochet led a bloody military takeover of the democratically elected government of Salvador Allende in 1973. Power in the new regime was concentrated in him personally. ${ }^{3}$ One of his first acts was to set up a high level military group, the National Intelligence Directorate (DINA), charged with eliminating the far left. ${ }^{4}$ The group operated under Pinochet's direct command, and was responsible for widespread human rights abuses, 5 including torture, mass arrests, murder and disappearances. ${ }^{6}$

\section{B Domestic Impunity}

In April 1978 the military junta issued Decree Law No 2191, which granted amnesty to perpetrators of criminal offences from 1973 to $1978 .{ }^{7}$

This amnesty had been a key feature in ensuring impunity for those involved in the offences, as the majority of the abuses occurred in the first four years of the regime. ${ }^{8}$ At the

3 Robert J Quinn "Will the Rule of Law End? Challenging Grants of Amnesty for the Human Rights Violations of a Prior Regime: Chile's New Model" (1994) Ford ham L Rev 905, 912.

4 Quinn, above n 3, 912.

5 Quinn, above n 3, 912.

6 Amnesty International "Chile: Torture: An International Crime" (22 October 1999) AI Index AMR.

7 Decree Law No 2191 (18 April 1978) Diario Oficial, No 30,042.

8 "United Kingdom: The Pinochet Case - Universal Jurisdiction and the Absence of Immunity for Crimes Against Humanity" (January 1999) AI Index: EUR 45/01/99. 
time of his arrest, Pinochet also benefited from personal immunity, in light of his position as Senator for life. ${ }^{9}$

The domestic bars to prosecution prompted the Spanish Courts to begin investigating Pinochet's crimes in 1996. However, with Pinochet in Chile, Spain was unable to proceed substantively with the case. ${ }^{10}$

Pinochet's private visit to the United Kingdom in 1998 created the opportunity to fill the missing component in the Spanish proceedings. On 16 October 1998, Spain sought his provisional arrest for the murder of Spanish citizens pending a formal extradition request. ${ }^{11}$ Later that day, Pinochet was arrested.

The arrest provoked a flurry of legal proceedings. Meanwhile Pinochet remained under in detention. $^{12}$

In November, the House of Lords met to consider an appeal against a High Court order quashing the second provisional warrant for Pinochet's arrest. By a majority of three to two,

9 "United Kingdom: The Pinochet Case", above n 8, 5. This immunity was removed by the Santiago Court of Appeal in June 2000.

10 Equipo Nizkor Special Report on the Preparation and Development of General Augusto Pinochet's Detention and Spanish Judges's Ruling Recognising the Principle of Universal Criminal Jurisdiction for Domestic Courts, (Madrid, 5 November 1998) 2 <http://www.derechos.org/nizkor/chile/juicio/report.html>.

The proceedings had been launched in Spain prior to Pinochet's arrival in Britain, but a trial in absentia was not possible. See Peter Weiss "Punishing Pinochet" (8 August 1998) CAQ no 64, $2<$ http: / / w w w.izquirda-unida.es/Derechos/Documentos/Art\%20peter\%20weis\%201998.htm> Human Rights Watch "Chile: When Tyrants Tremble: The Pinochet Case", $2<$ http: / / www.hrw.org/hrw/reports/1999/chile/>.

11 Initially the warrant was for murder. On 23 October, a second provisional warrant was executed following a second Spanish international warrant of arrest. It broadened the terms of the warrant from murder to torture, conspiracy to commit torture, hostage taking, conspiracy to commit hostage taking, and conspiracy to commit murder.

12 His first request, for habeus corpus, was declined. On 28 October the High Court granted certiorari to quash the second provisional warrant for his arrest, but Pinochet remained under arrest and the Court granted immediate leave for the Crown Prosecution Service to appeal its decision to the House of Lords. In November the Spanish National Court upheld the legality of the proceedings, in the face of a challenge by the Government of Spain. This resulted in a formal extradition request from Spain to the United Kingdom. For a full outline of the proceedings see Diana Woodhouse "Introduction: the Extradition of Pinochet: A Calendar of Events" in Diana Woodhouse (ed) The Pinochet Case: A Legal and Constitutional Analysis (Hart Publishing, Oregon, 2000) 1, 2-9. 
the Law Lords held that Pinochet's former position as Head of State in Chile did not render him immune from prosecution. ${ }^{13}$

The decision, broadcast live, ${ }^{14}$ was hailed as a victory for human rights. But the euphoria was short lived. In an almost unprecedented decision, an appeal committee of five Lords agreed that the judgment should be annulled on the grounds of possible bias. ${ }^{15}$

\section{THE SECOND HOUSE OF LORDS DECISION}

The second House of Lords case was heard before a full panel of seven Law Lords, none of whom was involved in the first case. The decision to appoint seven judges underlined the gravity of the case.

In the first House of Lords case, the legal arguments had related almost exclusively to the question of whether Pinochet was immune from prosecution in light of his former position as Head of State. In this second case, however, the House of Lords were faced with a new angle: whether the crimes were in fact extradition crimes within the meaning of the Extradition Act 1989. This issue had not been contested by the defence in the earlier hearings.

In short, the $6 / 7$ majority decision of the House of Lords was that:

(1) Pinochet's status as the former Head of State of Chile afforded him immunity in respect of his "official functions" performed while in office.

(2) The commission of torture is not an "official function" of a Head of State.

(3) Pinochet could be extradited only in respect of torture committed after 1988, as the United Kingdom did not have extraterritorial jurisdiction for crimes of torture prior to that time.

The decision that Pinochet could only be extradited for torture committed after 1988 drastically reduced the number of charges for which he could be extradited.

$13 R v$ Bow Street Metropolitan Stipendiary Magistrate ex p Pinochet Urgarte (No 1) [1998] 3 WLR, 1456 (HL).

14 Rosenberg, above n 2, 183.

$15 R v$ Bow Street Metropolitan Stipendiary Magistrate ex p Pinochet Urgarte (No 2) [1999] 4 All ER, 897 (HL). 


\section{A The Torture Convention and the Relevant Legal Concepts}

As context to the judgment, the relevant provisions of the Torture Convention and the international legal concepts underpinning it are outlined below.

\section{The Torture Convention}

The Convention Against Torture and Other Cruel, Inhuman or Degrading Treatment or Punishment 1984 ("The Torture Convention") sets up universal jurisdiction for crimes of torture in the domestic jurisdictions of the States Parties. Under Article 4 of the Torture Convention, States Parties must ensure that all acts of torture are offences under their domestic law. Under Article 5, parties are to establish jurisdiction to prosecute or extradite offenders with in their territory. ${ }^{16}$ The Convention is intended to ensure that there is no safe haven for torturers. ${ }^{17}$

All parties to the Pinochet proceedings, namely Britain, Spain and Chile, ratified the Torture Convention in 1988.

\section{Jus cogens}

A jus cogens rule is "a peremptory norm of general international law ... accepted and recognised by the international community of states as a whole as a norm from which no derogation is permitted and which can be modified only by a subsequent norm of general international law having the same character". ${ }^{18}$ Jus cogens laws have the highest status of all international laws and override other laws. ${ }^{19}$

16 See Matthew Lippman "The Development and Drafting of the United Nations Convention Against Torture and Other Cruel, Inhuman or Degrading Treatment or Punishment" (1994) 172 B C Int'l \& Comp L Rev 275, 316 .

17 J Herman Burgers and Hans Danelius The United Nations Convention Against Torture: A Handbook on the Convention against Torture and Other Cruel, Inhuman or Degrading Treatment or Punishment (Martinus Nijhoff Publishers, The Netherlands, 1988) 72.

18 Vienna Convention on the Law of Treaties 1969, art 53.

19 Robert Jennings and Arthur Watts (eds) Oppenheim's International Law I (9 ed, Longman Group UK Ltd, 1992) 4; Karen Parker and Lyn Beth Neylon "Jus cogens: Compelling the Law of Human Rights" (1999) 12 Hast Int'l \& Comp L Rev 411, 414-416; Andreas Zimmerman "Sovereign Immunity and Violations of International Jus cogens - Some Critical Remarks" (1995) 16 Mich L Rev 433, 437-438; M Cherif Bassiouni "International Crimes: Jus cogens and Obligatio erga omnes" (1996) 59 Law \& Contemp Probs 63, 67 . 


\section{Crimes against humanity}

Crimes against humanity are crimes of such seriousness that they strike at the conscience of humankind. Their gravity is such that their commission is seen as an attack against the international order. Accordingly, individuals who commit crimes against humanity are personally accountable to the international community and may be prosecuted under international law. ${ }^{20}$ The most up to date definition of crimes against humanity is contained in Article 7 of the Rome Statute of the International Criminal Court 1998. The crimes inclu ded are the following, when committed as part of a widespread or systematic attack ${ }^{21}$ again st a civilian population: murder, extermination, enslavement, ${ }^{22}$ deportation or forcible transfer of population, imprisonment, torture, rape, sexual slavery, enforced prostitution, forced pregnancy, enforced sterilisation or other grave sexual violence, persecution of a group in connection with another crime against humanity, disappearance, apartheid, or other inhumane acts causing great suffering or injury.

Genocide has similar legal characteristics to crimes against humanity but is sometimes categorised separately. ${ }^{23}$

The laws proscribing crimes against humanity and genocide are generally considered to be jus cogens. ${ }^{24}$

20 Christopher C Joyner "Arresting Impunity: The Case for Universal Jurisdiction in Bringing War Criminals to Accountability" (1996) 59 Law \& Contemp Probs, 153, 167; Ian Brownlie Principles of Public International Law (5 ed, Oxford, New York, 1998) 566-567. Article 6(c) of the Charter of the International Military Tribunal of Nuremberg conferred jurisdiction upon the Tribunal for "crimes against humanity, namely murder, extermination, enslavement, deportation, and other inhumane acts committed against any civilian population, before or during the war, or persecution on political, racial, or religious grounds in execution of or in connection with any crime within the jurisdiction of the Tribunal, whether or not in violation of the domestic law of the country where perpetrated."

21 Article 7(2) of the Rome Statute of the International Criminal Court makes it clear that an "attack" is not necessary a military attack.

22 Slavery is one of the oldest international crimes. For a discussion of the rules on the prosecution, extradition and punishment of slavery in the various Conventions outlawing slavery, see M Cherif Bassiouni and Edward M Wise Aut Dedere Aut Judicare: The Duty to Extradite or Prosecute in International Law (Martinus Nijhoff Publishers, The Netherlands, 1995) 132-156.

23 Genocide is criminalised under the Convention on the Prevention and Punishment of the Crime of Genocide 1948 (the Genocide Convention).

24 Bassiouni, above n 19,68 


\section{Immunity ratione personae}

Sitting Heads of State and diplomatic heads of mission have traditionally benefited from immunity ratione personae. This is a blanket immunity, attaching to the person of the office holder. It renders the incumbent immune from the civil or criminal jurisdiction of other states. It is based on the notion that one sovereign monarch should not be subject to the jurisdiction of another sovereign monarch, as they are of equal status. ${ }^{25}$ The immunity has existed for centuries, and historically existed to avoid offending the sovereign's dignity and mystique. ${ }^{26}$

\section{Immunity ratione materiae}

A former Head of State (and former head of a diplomatic mission) has traditionally benefited from immunity ratione materiae, a lesser immunity than that enjoyed during his or her tenure. The immunity is in respect of official functions performed while in office only, and is the same as that of the State itself. $^{27}$

\section{B Sovereign Immunity}

The first key question that the Law Lords considered was whether Pinochet could benefit from immunity ratione materiae, in light of his position as former Chilean Head of State.

The Law Lords initially looked at the relevant domestic statutes. Unlike the extradition question, however, which they decided turned on the domestic statutes, they considered that the statutes relevant to the immunity question reflected customary international law. They came to this view because under section 20(1)(a) of the State Immunity Act 1978, the Diplomatic Privileges Act 1964 applies, subject to "any necessary modifications", to a Head of State as if he or she were the Head of a diplomatic mission. The Diplomatic Privileges Act 1964 imports into United Kingdom law the Vienna Convention on Diplomatic Relations 1961, which provides that a diplomatic agent has immunity from criminal and civil jurisdiction until the agent leaves the post, but that the immunity subsists for acts performed "in the exercise of his

25 Arthur Watts "The Legal Position in International Law of Heads of State, Heads of Government and Foreign Ministers" (1994) III Recueil Des Cours 19, 52.

26 Malcolm M Shaw International Law (4 ed, Cambridge University Press, Cambridge, 1997) 492. For a useful description of the early development of Head of State immunity see William R Hartl "Sovereign Immunity: An Outdated Doctrine Faces Demise in a Changing Judicial Arena" (1993) 64 Nth Dak L $\operatorname{Rev} 401,402-4$.

27 Watts, above n 25, 88-89. 
functions". ${ }^{28}$ At international law, too, a former Head of State has immunity in respect of official functions performed during his or her tenure.

The majority Law Lords held, in a compellingly simple conclusion, that the commission of torture could not be an "official function" of a Head of State, and that immunity ratione materiae was therefore unavailable to Pinochet. This is the first time that a domestic court has held that a former Head of State of a foreign country is not immune from its criminal jurisdiction. However they also expressed obiter views that sitting Heads of State are inviolable. ${ }^{29}$

\section{Does the absence of im munity ratione materiae for torture extend to other crimes against humanity?}

The question of whether immunity ratione materiae was unavailable because torture is a crime against humanity, or because torture is outlawed by the Torture Convention, to which Britain and Spain were signatory, is pivotal when assessing the implications of the judgment. If it was the latter, the judgment will be narrow in its effect on international law. If, however, it was the former, then the case will have broad reaching ramifications, as it will provide au thority for the prosecution of former Heads of State in domestic courts for any crimes against humanity. ${ }^{30}$

A variety of reasons were advanced by the Law Lords when concluding that Pinochet was not immune to charges of torture. The reasoning of the different judges on this important issue is complex, so it is analysed below in some detail.

The underlying rationale for Lord Browne-Wilkinson's conclusion that immunity is unavailable for torture is not immediately apparent from his

28 A less circuitous route to the same conclusion was in fact available to the Law Lords. Section 20(1)(a) of the State Immunity Act applies the Diplomatic Privileges Act 1964 to "a sovereign or other head of State". The absence of a temporal element in the section would suggest that it refers only to sitting sovereigns and Heads of State. As there is no statutory provision codifying the immunity of former Heads of State, the Law Lords could have immediately applied customary international law, on the basis that it forms part of British common law.

29 Pinochet No 3, above n 1, Lord Browne-Wilkinson, 844; Lord Hope of Craighead, 886; Lord Saville of Newdigate, 903; Lord Millet, 905 and 913; Lord Phillips, 916.

30 The Genocide Convention applies to "constitutionally responsible rulers, public officials, or private individuals". However the Convention's absence of immunity does not necessarily extend to genocide tried in foreign domestic courts, as the Convention does not empower States Parties to prosecute ge nocide extraterritorially. 
judgment. Initially, he seemed to suggest that immunity did not apply because torture is jus cogens and a crime against humanity. ${ }^{31}$ Later, he indicated that the immunity existed prior to the Torture Convention, seemingly contradicting his acknowledgment that torture was an international crime of jus cogens character at that time. ${ }^{32} \mathrm{H}$ is rationale for the conclusion that immunity subsisted until the Torture Convention was that it was only after the Torture Convention that torture could be considered a "fully constituted international crime". He suggested that in order for an international crime to become "fully constituted" it needs "some form of universal jurisdiction" and said that the Torture Convention provided that missing mechanism. Notwithstanding his views on the need for "universal jurisdiction in respect of a particular crime in order for immunity to be dislodged", Lord Browne-Wilkinson did not restrict the absence of immunity ratione materiae to acts of torture. When making his observations that torture was not a fully constituted international crime prior to the Torture Convention, Lord Browne-Wilkinson said "at that stage there was no international tribunal to punish torture and no general jurisdiction to permit or require its punishment in domestic courts", thereby indicating that the existence of an international criminal tribunal may create the requisite universal jurisdiction. The Rome Statute of the International Criminal Court 1998 sets up such a tribunal, to prosecute, inter alia, crimes against humanity. Accordingly, all crimes against humanity could be seen as fully constituted international crimes under Lord Browne-Wilkinson's criteria. Immunity ratione materiae would not attach to crimes against humanity committed after the signing of the Rome Statute of the International Criminal Court in 1998.33

31 Pinochet No 3, above n 1, 846 per Lord Browne-Wilkinson.

32 Pinochet No 3, above n 1, 846 per Lord Browne-Wilkinson.

33 It is also arguable that immunity ratione materiae would subsist until the Rome Statute of the International Criminal Court came into force, which occurs following deposit of the $60^{\text {th }}$ instrument of ratification, approval acceptance or accession. As at 4 May 2001 there were 139 signatories and 30 parties. 
Lord Hope of Craighead accepted the reasoning of Lord Slynn of Hadley ${ }^{34}$ from the first House of Lords judgment, that in order for immunity ratione materiae to be unavailable to a person accused of a crime, the state asserting and the state being asked to refuse immunity must each be party to a Convention defining the act as a crime at international law and empowering the state to prevent or prosecute the crime extraterritorially. In countries such as the United Kingdom where conventions are not self executing, the Convention must also have been incorporated into domestic law. ${ }^{35} \mathrm{He}$ also considered that the crime must have been committed as part of a systematic policy. ${ }^{36}$ The effect of this reasoning would be that immunity ratione materiae is only dislodged where the crime in question is systematic torture or apartheid, and the parties to the proceedings are signatories to and have implemented the terms of the relevant convention. This is because only the Apartheid Convention and the Torture Convention set up universal domestic jurisdiction for crimes against humanity. ${ }^{37}$ Similarly, Lord Saville of New digate said that Chile, Spain and Britain, by becoming parties to the Torture Convention, had agreed to an exception to the general rule of immunity ratione materiae - suggesting that immunity ratione materiae would continue to apply to other crimes against humanity.

Lord Millet and Lord Phillips took the most expansive approach. Lord Millet considered that internationally criminal acts committed by a sovereign power by their very nature attract individual criminal responsibility. ${ }^{38} \mathrm{He}$ expressed the view that universal jurisdiction for crimes against humanity has existed since "well before 1984". Lord Phillips similarly concluded "if Senator Pinochet behaved as Spain alleged, then the entirety of his conduct was a

34 The fact that Lord Hope of Craighead quoted Lord Slynn of Hadley is itself of interest in that it provides authority to the first House of Lords judgment.

35 Pinochet No 3, above n 1, 882 per Lord Hope of Craighead.

36 Pinochet No 3, above n 1, 886 per Lord Hope of Craighead.

37 Article 4(b) of the Convention on the Suppression and Punishment of the Crime of Apartheid 1973 requires states to adopt legislation to bring to trial persons accused of apartheid, whether or not they reside in the territory of the state in which the acts are committed. Under art 5, persons who have committed apartheid may be tried by any state party which may acquire jurisdiction over the person. The Genocide Convention does not empower states parties to prosecute genocide extraterritorially (see art 6 which says persons shall be tried in the territory where the act was committed or by an international penal tribunal accepted by the contracting parties). However art 4 of the Genocide Convention expressly applies the Convention to officials and rulers.

38 Pinochet No 3, above n 1,914 per Lord Millet. 
violation of the norms of international law. He can have no immunity for prosecution for any crime that formed part of that campaign." ${ }^{39}$ Both judgments are therefore clear authority for the proposition that immunity ratione materiae is not available for any crime against humanity. Lord Hutton appears to favour a similar approach, implying that immunity is unavailable for any international crime. ${ }^{40}$

Thus, the majority of the Law Lords were of the view that immunity ratione materiae cannot be invoked in respect of any crime against humanity. This may pave the way for the future indictment, in domestic jurisdictions, of state agents, and former Heads of State who have committed crimes against humanity.

\section{The treatment of murder charges}

The Law Lords' views on whether Pinochet was immune to charges of murder are, however, also relevant to the question of whether the decision on the unavailability of immunity for torture is applicable to other crimes against humanity. The prosecution did not argue that immunity was unavailable to Pinochet for the charges of murder and conspiracy to murder. ${ }^{41}$ Nevertheless Lord Phillips held that immunity did not exist for conspiracy to murder as the entirety of his conduct formed part of a campaign that violated international law. ${ }^{42}$ Lord Millet reached the same conclusion, although not because conspiracy to murder on the scale alleged was a crime against humanity but because it took place in Spain, the forum country. ${ }^{43}$ The other majority Law Lords held that Pinochet had immunity in respect of the murder charges. ${ }^{44}$

39 Pinochet No 3, above n 1, 925 per Lord Phillips. Lord Phillips' earlier statements, however, are not entirely consistent with this conclusion. For example at 924 he suggests that if the Genocide Convention had not expressly held responsible rulers and public officials liable, an issue could have been raised as to whether the jurisdiction conferred by the Convention was subject to immunity ratione materiae.

40 Pinochet No 3, above n 1,900-901 per Lord Hutton.

41 Pinochet No 3, above n 1,848.

42 Pinochet No 3, above n 1, 925, 927 per Lord Phillips.

43 Pinochet No 3, above n 1,913 per Lord Millet.

44 Pinochet No 3, above n 1, 848 per Lord Browne-Wilkinson; 887 per Lord Hope; 888 per Lord Hutton; 904 per Lord Saville (by inference). 
There is some tension between the decision of Lords Browne-Wilkinson and Hutton that immunity existed for murder, and their conclusion that immunity was unavailable for torture, given that the stated rationale for their conclusion on torture could be extended to all crimes against humanity. This is because systematic murder is categorised as a crime against humanity. ${ }^{45}$ The Law Lords should therefore have assessed whether the murder had been committed on such a scale as to constitute a crime against humanity. If the answer was in the affirmative, then, applying their own reasoning, immunity should have been unavailable.

\section{Liability of sitting Heads of State}

The issue of the liability of sitting Heads of State was dealt with only briefly. Five of the six majority judges said that sitting Heads of State were immune from any form of civil or criminal suit. They were technically correct under United Kingdom domestic law. Section 20(1) of the State Immunity Act 1978 has the effect of rendering Heads of State "inviolable", by importing and applying to Heads of State diplomatic immunities under article 29 of the Vienna Convention on Diplomatic Relations 1961. However at international law the situation is much less clear cut, and the Law Lords did not distinguish between domestic and international law when asserting the inviolability of an incumbent sovereign.

The Law Lords relied on the views of prominent commentator Sir Arthur Watts to assist them in their arguments that former Heads of State who commit international crimes are not subject to immunity. ${ }^{46}$ However Sir Arthur does not distinguish between sitting and former Heads of State when concluding that: ${ }^{47}$

As a matter of general customary international law a Head of State will personally be liable to be called to account if there is sufficient evidence that he authorised or perpetrated such serious international crimes.

This important point was not acknowledged in the judgment.

45 This was confirmed in 1998 by the Rome Statute of the International Criminal Court.

46 Pinochet No 3, above n 1, 846 per Lord Browne-Wilkinson; 881 and 886 per Lord Hope; 888 per Lord Hutton; 919 per Lord Phillips.

47 Watts, above n 25,84 
Over the last century both sitting and former Heads of State have in practice been considered to be liable for the commission of international crimes. The first person to be held accountable for crimes against international peace was the former German Emperor, Kaiser Wilhelm II, who was indicted after World War One. ${ }^{48}$ In 1945, the Allies were planning to bring Hitler to justice while he was still Head of State in Germany. ${ }^{49}$ Since then, a raft of international instruments, from the Nuremberg Charter 1946 to the Statute of the International Criminal Court 1998, extend criminal responsibility to Heads of State. ${ }^{50}$ The liability of sitting Heads of State for international crimes was forcefully confirmed just two months after the Pinochet decision, when the International Criminal Tribunal for the Former Yugoslavia issued a warrant for the arrest of the President of the Federal Republic of Yugoslavia for war crimes. ${ }^{51}$

However all those cases and instruments involve the punishment of sitting Heads of State by international tribunals rather than domestic courts. This raises the question of whether there is a valid policy or legal basis for a distinction between the liability of a Head of State before a domestic court and an international tribunal.

Legal commentators do not appear to have addressed the specific question of whether there should be a distinction between domestic and international prosecution of Heads of State for international crimes. However the Nuremberg Tribunal, which had express jurisdiction over Heads of State ${ }^{52}$ is described by legal commentators as having been a joint exercise, by the four states which established it, of a jurisdictional right which each was entitled to exercise

48 Shigeru Oda "The Individual in International Law" in Max Sorensen (ed) Manual of Public International Law (Macmillan, New York, 1968) 469, 515.

49 "United Kingdom: The Pinochet Case", above n 8, 24.

50 Article 6 of the Charter of the International Military Tribunal for the Far East 1946, art 7 of the Nuremberg Charter, art IV of the Convention for the Prevention and Punishment of the Crime of Genocide (1948), Principle III of the Principles of Law Recognised in the Charter of the Nuremberg Tribunal and the Judgment of the Tribunal (1950); art 3 of the UN Draft Code of Offences against the Peace and Security of Mankind (1954), art 7(2) of the Statute of the International Criminal Tribunal for the Former Yugoslavia, art 6(2) of the Statute for the International Criminal Tribunal for Rw anda 1994, art 7 of the UN Draft Code of Crimes Against the Peace and Security of Mankind 1996, and most recently art 27 of the Statute for the International Criminal Court 1998.

51 The Prosecutor of the Tribunal v Slobodan Milosovic Warrant of Arrest/ Order for Surrender (24 May 1999) Case No. IT-99-37-I.

52 Charter of the International Military Tribunal at Nuremberg, art 7. 
separately in accordance with international law. ${ }^{53}$ This suggests that the individual states each possessed the right to override the immunity of a Head of State who had committed war crimes or crimes against humanity.

From a policy perspective it may be argued that Head of State immunity before foreign courts is necessary to guard against political problems that might result in the state from which the leader originates if he or she were arrested overseas. However this argument is not without its problems. First, if the leader is committing crimes against humanity, the political void might have a stabilising rather than a destabilising effect on the regime. In the event, however, that the leadership vacuum did create instability, the jurisdiction in which the Head of State was being tried would be of marginal if any relevance.

A stronger basis for creating a distinction between the liability of a Head of State before a domestic court and an international tribunal is the possible political repercussions for the prosecuting state. However that rationale raises questions when assessed in the context of the principles behind both the universal jurisdiction for crimes against humanity and Head of State immunity. Crimes against humanity may be prosecuted internationally, as they are of such gravity that they are viewed as an attack on the international order. Thus the prosecuting state can be seen as operating on behalf of the international community rather than in its usual role as a municipal jurisdiction of equal status to other states. Furthermore, the "dignity" and "mystique" of a sovereign are irretrievably eroded when he or she commits crimes against humanity. The case for prosecuting crimes against humanity seems especially convincing where the accused is a sitting Head of State, as to punish the person with ultimate control over a regime in which crimes against humanity are being committed is likely to be the most effective means to end those crimes.

The Pinochet case would have been an ideal context in which to deal with the issue of sitting Heads of State. An obiter statement as to the liability of sitting Heads of State could have been made without the potential adverse political consequences associated with an actual case. Such a statement would have sent a warning to all sitting Heads of State that crimes against humanity will not go unpunished, thereby setting in place a strong self executing accountability mechanism and deterrent against future abuses. Importantly, it would also have avoided the possibility that the judgment would discourage criminal Heads of State from ceding power, at risk of losing their absolu te immunity.

53 See for example Oppenheim's International Law Vol II (7 ed, Longman Group UK Ltd, Essex, 1952) 580581 . 
The Law Lords' pronouncements on the inviolability of sitting Heads of State, however, should not be afforded significant precedential value, as Pinochet was not a sitting Head of State, and the British statutory scheme underlay the conclusion. They do not detract from the groundbreaking decision that immunity is unavailable for former Heads of State who commit torture and other crimes against humanity.

\section{Extradition}

If Pinochet could not rely on Head of State immunity to prevent his extradition, the question still remained as to whether he was liable to be extradited for the crimes he was alleged to have committed. In the view of the majority, he was only liable to be extradited for torture after 1988, when extraterritorial torture was made a statutory offence in the United Kingdom.

This section of the paper argues that the Law Lords: ${ }^{54}$

(1) Took an unduly restrictive interpretation of section 2 of the Extradition Act 1989 (UK) in deciding that the date that the offence needed to have been criminal in Britain was the date of the Act rather than the date of the extradition request; and

(2) Failed to consider underlying international legal norms that could have permeated the domestic statutory scheme, and facilitated his extradition on all counts of torture.

\section{The decision on extradition}

The point that the lawyers for Pinochet argued at the new hearing, that was considered to be the pivot upon which the case turned, was the absence of the requisite "double criminality" in respect of the torture charges. Under the generally accepted principles of extradition law, and standard extradition treaties, the state with the alleged criminal in its territory will not extradite unless the crime alleged to have been committed is a crime within its own jurisdiction. The laws of the United Kingdom reflect this principle. A primary purpose behind that rule is encapsulated in the concept "nulla poena sine lega" or "no punishment without law". ${ }^{55}$ In other words, it is contrary to justice for State A to agree to extradite a person to State

54 Other than Lord Millet.

55 Sharon A Williams "The Double Criminality Rule and Extradition: A Comparative Analysis" (1991) 15 Nov L Rev 581, 582. 
B if the person concerned was going to be punished for an act that State A did not consider illegal.

\section{The issue}

It is necessary to explain in some detail the provisions of the Extradition Act 1989 (UK), since the minute construction of its terms resulted in the decision that extradition could not be effected for the majority of the charges.

The Extradition Act 1989 (UK) defines "extradition crimes" in section 2. Section 2(1)(b) has a specific definition relating to extraterritorial extradition crimes, that is, crimes committed outside the territory of the United Kingdom. Accordingly, under the Act, both the criminal act in question, and the jurisdictional basis for the criminality of that act are relevant to the question of double criminality.

The acts at issue were torture committed outside Spain, and Spain was asserting an extraterritorial right to try the torture. Thus, the criminal offence that needed to exist in the United Kingdom law was extraterritorial torture.

Section 2(1)(b) of the Extradition Act 1989 defines extraterritorial extradition crimes as follows:

(b) an extra-territorial offence against the law of a foreign state ... which is punishable under that

law with imprisonment for a term of 12 months, or any greater punishment, and which satisfies -

(i) the condition specified in subsection (2) below;

The issue lay in the "condition" referred to in section 2(1)(b)(ii) that needs to be satisfied in order for the offence in question to be an "extraterritorial crime". Section 2(2) defines the "condition" as follows:

(2) The condition mentioned in subsection (1)(b)(i) above is that in corresponding circumstances equivalent conduct would constitute an extra-territorial offence against the law of the United Kingdom punishable with imprisonment for a term of 12 months, or any greater punishment.

\section{Pinochet's arguments}

Pinochet's lawyers argued that the words "would constitute an extraterritorial offence" should be read as requiring the relevant date for considering whether the offence was criminal in Britain to be the date of the offence itself, rather than the date of the extradition request. 
The relevance of that argument is that torture was not a statutory extraterritorial offence in Britain until the passage of section 134 of the Criminal Justice Act 1988, after Britain had acceded to the Torture Convention. However the crimes subject to the extradition request related almost exclusively to events prior to 1988 .

\section{The majority view}

In considering this issue, Lord Browne-Wilkinson, who delivered the main judgment on the extradition question, observed that the words "would constitute an offence..." in the Extradition Act "read more easily" as relating to a hypothetical occurrence in the United Kingdom at the time of the extradition request than at the time of the criminal act. ${ }^{56} \mathrm{He}$ nevertheless chose to go beyond the section, and looked to the broader scheme of the Act. The factor that he seemed to consider most persuasive, in leading him to the conclusion that the relevant date was the date of conduct of the offence, was that the Act which preceded the Extradition Act 1989, the Extradition Act 1870, contained a list of extradition crimes to be construed according to "the law existing in England... at the date of the alleged crime". ${ }^{57}$ Lord Browne-Wilkinson concluded that the lack of reference in the travaux preparatoires of the 1989 Act to the need to change the date demonstrated that Parliament must have intended that the date (that is, the time of commission of the offence) remain the same in the new Act. $\mathrm{He}$ suggested it was "impossible" that Parliament could have intended to change the date "by side wind and without investigation". 58

This restrictive construction of the Extradition Act meant that Pinochet could only be extradited for torture occurring after 1988.

\section{International law on extradition for crimes again st humanity}

The decision not to extradite Pinochet for torture prior to 1988 did not technically breach the Torture Convention as interpreted by the United Nations Committee Against Torture. ${ }^{59}$ The Committee decided in 1989 in the context of three communications by the relatives of Argentinian torture victims seeking to overturn an Act that predated the Convention, that the

56 Pinochet No 3, above n 1,839 per Lord Browne-Wilkinson.

57 Pinochet No 3, above n 1,839 per Lord Browne-Wilkinson.

58 Pinochet No 3, above n 1, 839 per Lord Browne-Wilkinson.

59 If the Convention had been retrospective art 7 would have been breached. The Law Lords did not discuss the Torture Convention in the context of the extradition question. 
Convention does not have retrospective effect. They held that "torture for the purposes of the Convention can only mean torture that occurs subsequent to the entry into force of the Convention". ${ }^{60}$

In spite of the apparent consistency of the decision with the Torture Convention, there are arguably underlying international legal principles that support an application of extradition laws to facilitate Pinochet's prosecution for all counts of torture. The Torture Committee, in the context of the 1988 decision stated that prior to the entry into force of the Convention international law already obliged "all states to take effective measures to prevent torture and to punish acts of torture." 61 The Committee considered that the law in question (guaranteeing impunity for certain military) was incompatible with the spirit and purpose of the Convention, and that the Argentinian government had a "moral obligation" to compensate relatives of the victims.

There is rapidly evolving support at international law for the notion that states have a duty to facilitate prosecution of all crimes against humanity. The orthodox view has been that states

60 Communications Nos 1/1988, 2/1988 and 3/1988, Report of the Committee Against Torture, United Nations, New York 1990, 112

61 Report of the Committee Against Torture, above n 60, 112. A distinction between preexisting international law and the Torture Convention was acknowledged in the preamble to the Torture Convention, which refers to international laws banning torture that predated the Convention, (art 5 of the Universal Declaration on Human Rights, and art 7 of the International Covenant on Civil and Political Rights), and states as a purpose of the Convention the "[desire] to make more effective the struggle against torture and other cruel, inhuman or degrading punishment throughout the world." The Handbook on the Convention Against Torture and Other Cruel, Inhuman or Degrading Treatment or Punishment reinforces this point as follows:

Many people assume that the Convention's principal aim is to outlaw torture and other cruel, inhuman, or degrading treatment or punishment. This assumption is not correct insofar as it would imply that the prohibition of these practices is established under international law by the Convention only and that this prohibition will be binding as a rule of international law only for those states which have become parties to the Convention. On the contrary, the Convention is based on the recognition that the above-mentioned practices are already outlawed under international law. The principal aim of the Convention is to strengthen the existing prohibition by a number of supportive measures.

Above n 17, 1 . 
have a right to prosecute crimes against humanity. ${ }^{62}$ Some commentators, however, consider the need to punish the perpetrators of jus cogens crimes is so fundamental that states are subject to an obligatio erga omnes or non derogable duty to prosecute or extradite. ${ }^{63}$ There is strong argument to suggest that the recent adoption of the Rome Statute of the International Criminal Court 1998 has significantly increased momentum towards the existence of such an obligation. ${ }^{64}$ There has also been recent judicial endorsement of this principle. In September 1999, the Federal Court of Australia accepted the existence of an obligatio erga omnes in the context of genocide. ${ }^{65}$

In 1985, the French Court of Cassation endorsed a firm statement by the French Court of Appeal which provides guidance as to how the obligatio erga omnes principle might impact on municipal extradition laws. The Court of Appeal stated, in the context of an appeal by a former Gestapo agent against his detention by French agents that "crimes against humanity ... are subject to an international criminal order to which the notions of frontiers and extradition rules arising therefrom are completely foreign." 66 That case should not be seen as authority for the proposition that the state being asked to extradite is entitled to ignore extradition laws, not least because it related to the legality of a de facto extradition that had already been effected by

62 Christopher C Joyner "Arresting Impunity: The Case for Universal Jurisdiction in Bringing War Criminals to Accountability" (1996) 59 Law \& Contemp Probs, 169. Robert Jennings and Arthur Watts (eds) Oppenheim's International law (9 ed, Longman Group UK Ltd, Essex, 1992) 998.

63 For example Bassiouni, above n 19, 65-66; "United Kingdom, The Pinochet Case", above n 8, 9; Bassiouni and Wise, above n 22, 112-131. The "erga omnes" principle has been referred to by the International Court of Justice in the following cases: Barcelona Traction, Light and Power Co Ltd (Belg $v$ Spain) [1970] ICJ 3; Reservations to the Convention on the Prevention and Punishment of Genocide [1951] ICJ Rep 15; South West Africa Cases (Preliminary Objections) Ethiopia v South Africa; Liberia v South Africa [1963] ICJ Rep 319.

64 In 1997 M Cherif Bassiouni wrote "it is still uncertain in ICL [international criminal law] whether the inclusion of a crime in the category of jus cogens creates rights or, as stated above, non-derogable duties erga omnes. The establishment of a permanent international criminal court having inherent jurisdiction over these crimes would be a convincing argument for the proposition that crimes such as genocide, crimes against humanity, and war crimes are part of jus cogens and that obligations erga omnes to prosecute or extradite flow from them." Bassiouni, above n 19, 74.

65 Nulyarimma $v$ Thompson [1999] FCA 1192, 21 per Merkel J <http://www.austlii.edu.au/au/ cases/cth/federal_ct/1999/1192.html>.

66 Federation Nationale Des Deportes et Internes Resistants et Patriotes and Others $v$ Barbie Court of Cassation Criminal Chamber (1985) 87 ILC Lauterpacht 125, 130. 
the French Government. ${ }^{67}$ However it underlines, in a general sense, the fundamental concern that the prosecution of crimes against humanity is to the international community, and suggests that municipal extradition laws should not operate to obstruct that goal.

\section{Alternative approaches to the extradition question}

There were three approaches that the Law Lords could have adopted, consistent with domestic and international extradition laws and the obligatio erga omnes principle, that would have ensured that Pinochet was extradited for all counts of torture. These were:

(1) Resolution of the ambiguity in the Extradition Act in favour of double criminality.

(2) Retrospective application of the Criminal Justice Act 1988.

(3) Importation of customary intern ational law.

(a) Resolution of ambiguity in favour of double criminality

Lord Browne-Wilkinson's interpretation of section 2(2) of the Extradition Act 1989, adopted by all the Law Lords, is open to question. He considered that Parliament could not have intended to change the date at which the act in question needed to be criminal (viz the date of the act itself) because the travaux preparatoires did not mention an intention to make such a change. However it is equally arguable that the removal in the 1989 Act of a reference to a requirement for extradition crimes to be criminal in English law "at the date of the alleged crime" removed the requirement for the crime to be criminal in Britain at the time of its commission. This interpretation seems logical when viewed in the context of Lord BrowneWilkinson's comment that the words of section 2(2) "read more easily" as the date of the extradition request. Such an interpretation would be consistent with the "nulla poena sine lege" purpose of the double criminality rule. Extraterritorial torture is currently unlawful in Britain, and therefore to extradite for such a crime to a country which criminalised it earlier would not appear to be contrary to British notions of justice. ${ }^{68}$ The obligatio erga omnes principle would

67 For other examples of de facto extraditions (including Adolf Eichmann) see I A Shearer Extradition in International Law (Manchester University Press, Manchester, 1971) 73.

68 An alternative rule of interpretation might also have been invoked. Under that rule, if a statute is ambiguous, regard might be had to the consequences of the alternative construction. The general rule is that where statutes are clear, the particular consequences in the case before the judges may not be considered. Where a statute is ambiguous, regard may be had to the consequences of the alternative construction. Halsburys Laws of England (4 ed, Butterworths, London) vol 44, Statutes, paras 895 and 896,548 and 549. 
suggest that the ambiguity ought to have been resolved in favour of extradition, in accordance with the principle that legislative ambiguities are to be construed where possible in accordance with international law. ${ }^{69}$

(b) Retrospective application of the Criminal Justice Act

The judges presupposed the prospectivity of section 134 of the Criminal Justice Act 1988, thereby failing to address a compelling basis for securing Pinochet's extradition on all counts of torture: to apply the section retrospectively.

Numerous international treaties prima facie prohibit retrospective criminal laws. Article 11(2) of the Universal Declaration on Human Rights states "No one shall be held guilty of any penal offence on account of any act or omission which did not constitute a penal offence, under national or international law, at the time when it was committed". Articles 15 of the International Coven ant on Civil and Political Rights, and 7(1) of the European Convention of Human Rights mirror that provision. The rule derives from the notion that people should be able to determine the boundaries of legality and adapt their actions in accordance with those boundaries. ${ }^{70}$ It is intended to protect people from punishment for acts which they believed to be lawful. However acts that are offences at international law are not covered by the prohibition. Thus, a legal process which allows a person to be convicted under domestic law for a pre-existing offence at international law does not conflict with the relevant international instruments. The crimes to which universal jurisdiction applies, namely war crimes and crimes against humanity, constitute the gravest offences known to humankind, rendering the rationale underlying the rule against retrospectivity of marginal relevance.

United Kingdom law similarly operates on the principle that penal statutes are not to be applied retrospectively. ${ }^{71}$ However the principle is a presumption only, and has occasionally been dislodged in cases where the relevant offence did not pre-exist at international law. ${ }^{72}$

69 Halsburys Laws of England (4 ed, Butterworths, London) vol 44, Statutes, para 908, 559. For a general discussion of British interpretation of international laws see Tom Rensen "British Statutory Interpretation in Light of Community and Other International Obligations" (1993) 14 Stat Law Rev 186. For the American situation see Ralph G Steinhardt "The Role of International Law As a Canon of Domestic Statutory Construction" (1990) 43 Vand LR 1103.

70 Rupert Ticehurst "Retroactive Criminal Law" (1998-99) 9 Kings College LJ 89.

71 The Interpretation Act 1978 (UK) is silent on the issue. The Human Rights Act 1998 (UK) requires legislation to be read in a way which is compatible with rights under the Eurpoean Convention on Human Rights. Article 7 of the Convention proscribes the retrospective application of criminal laws, 
A cogent case for rebutting the presumption against retrospectivity existed in the Pinochet case. Section 134 of the Criminal Justice Act simply codified pre-existing international law, under which the United Kingdom (together with all other nations) already had jurisdiction to try crimes of torture. ${ }^{73}$

The Law Lords were therefore neither constrained by statute, precedent, nor international law from holding that section 134 of the Criminal Justice Act applied retrospectively to criminalise extraterritorial torture prior to 1988 .

(c) Importation of Customary Internation al Law

An alternative related approach was taken by Lord Millet. His view was that torture was an extraterritorial crime in Britain prior to 1988 under the common law, and therefore that the courts had jurisdiction to extradite for all counts of torture.

There were two limbs to his reasoning:

(1) That universal jurisdiction existed at customary international law for torture prior to 1988.

but only where they did not constitute a criminal offence under national or international law at the time of commission.

72 An example is the 1992 case of $R v R$ [1992] 1 AC 599 (HL) in which the common law defence of marital relations to statutory rape was removed. This was challenged before the European Court of Human Rights, as being contrary to art 7 of the European Convention on Human Rights, which proscribes retrospective criminalisation of offences. In its decision upholding the judgment, the Court was influenced significantly by the severity of the offence of rape, saying "the essentially debasing character of rape is so manifest" CR v United Kingdom, No 20190/92 (1995) 21 EHRR 363, 402. In Shaw v $D P P$ [1962] AC 220 (HL), the common law offence of "conspiracy to corrupt public morals" was created.

The War Crimes Act 1991 (UK) is Britain's only retrospective criminal statute. This extends to United Kingdom courts' jurisdiction over murder, manslaughter, and culpable homicide committed in German territory during the Second World War.

73 See Kevin J Liss "The Ex Post Facto Prohibition and the Exercise of Universal Jurisdiction over International Crimes" (1987) 87 Columb LR 1515, 1528. Compare Justice Robert Jackson "Report of 7 June 1945" (1945) 39 Am J Int'l L Supp 178, 187 in which the retrospective application of the Nuremberg statute was justified by the Chief of Council for the United States on the basis that international law is not capable of legislative development so can not grow unless new principles are adopted and applied. 
(2) That customary international law automatically forms part of the common law of the United Kingdom.

Lord Millet reasoned that torture was an extraterritorial crime in Britain well before 1973, in spite of the absence of a legislative provision to that effect. He was of the view that universal jurisdiction existed for all crimes against humanity at the time of the Nuremburg Tribunal, and it was only the language of the Nuremberg Charter that restricted the scope of its jurisdiction in respect of crimes against humanity to those committed in connection with war crimes. ${ }^{74}$ The finding that universal jursidiction existed for torture and other crimes against humanity at the time of Nuremberg is a progressive interpretation of customary international laws at that time. $^{75}$

In drawing his conclusion Lord Millet invoked the "incorporationist" doctrine of international law, under which customary international law is imported directly into the common law without need for an implementing domestic statute. This doctrine facilitates domestic consistency with international human rights as it enables ongoing and direct implementation of evolving international norms in national jurisprudence without the need for law changes. His Lordship did not see the need to traverse the authorities in drawing the conclusion, in spite of some inroads into the doctrine in United Kingdom case law. ${ }^{76}$ His definitive statement that "[c]ustomary international law is part of the common law" may well assist in settling the doctrine, and will be a strong precedent for future direct incorporation of international human rights and other laws into common law jurisdictions.

74 Pinochet No 3, above n 1, 909.

75 Joyner, above n 20, 160 has similar views. Compare Brownlie, above n 20, 566-567; Tristan Gilbertson "Legal Implications of the Presence of Nazi War Criminals in New Zealand" (1988-91) 6 Auck U LR 552, 556-557.

Lord Millet consolidated his reasoning on which crimes attract universal jurisdiction into a useful formula. He held that all international crimes attract universal jurisdiction if the crime is jus cogens and has been committed on a serious scale. He said torture and genocide are the most serious crimes against humanity, and that torture has been expressly prohibited at least since 1948, when the Universal Declaration of Human Rights came into effect. Lord Millet's formulation of crimes that attract universal jurisdiction is likely to become an important tenet of international law, and has already been referred to by Merkel $\mathrm{J}$ in the Australian Federal Court genocide case of Nulyarimma $v$ Thompson, above n 65, 28 .

76 Brownlie, above n 20, 42-47. 


\section{THE NEW ZEALAND SITUATION}

What, then, is the position in New Zealand?

This part of the paper considers the New Zealand statutory framework and common law on sovereign immunity, crimes against humanity, and extradition at the time of the Pinochet proceedings.

\section{A Immunity}

\section{Sovereign immunity}

In contrast with the United Kingdom, New Zealand does not have legislation governing state or Head of State immunity. Sovereign immunity is part of the common law. The leading case on sovereign immunity is Governor of Pitcairn $v$ Sutton. ${ }^{77}$ In that case Cooke P expressed the paramouncy of international law in respect of matters such as sovereign immunity, going so far as to state that: ${ }^{78}$

A general statute, however apparently comprehensive, is not to be interpreted as contrary to international law on such matters as sovereign immmunity. Some sufficiently plain positive indication is required to produce such a result.

Sovereign immunity was held in that case to form part of New Zealand law, thereby precluding a New Zealand based employee of the British Government from seeking relief under the Employment Contracts Act 1991.

\section{Head of State immunity}

There is no specific case law in New Zealand on the immunity of Heads of State. In Governor of Pitcairn $v$ Sutton, Richardson J indicated that New Zealand would apply British common law on sovereign immunity unless local factors or policy considerations weighed against its application. ${ }^{79}$ This suggests that New Zealand would be likely to follow the Pinochet decision on the liability of former Heads of State for crimes against humanity.

Unlike in the United Kingdom, New Zealand courts would not be constrained by domestic legislation from holding a sitting Head of State accountable for a crime against humanity. In

77 Governor of Pitcairn v Sutton [1995] 1 NZLR 426 (CA).

78 Governor of Pitcairn $v$ Sutton, above n 77, 30.

79 Governor of Pitcairn v Sutton, above n 77, 436. 
Governor of Pitcairn $v$ Sutton Richardson J endorsed international law as a source of New Zealand common law, ${ }^{80}$ and stated "the Courts of New Zealand will always seek to develop and interpret our laws in accordance with generally accepted international rules and to accord with New Zealand's international obligations." 81 It would thus be open to the courts to hold that sitting Heads of State are liable for international crimes under customary international law, and that this should be incorporated into New Zealand law through the common law.

\section{Other immunities}

If the New Zealand courts were to hold that a sitting Head of State was not immune from prosecution for a crime against humanity under customary international law, the situation as between sitting Heads of State and diplomatic agents in office would be anomalous. A diplomatic agent in New Zealand is subject to full legislative immunity. Similarly to the United Kingdom's Diplomatic Privileges Act, the Diplomatic Privileges and Immunities Act 1968 directly im ports into New Zealand law the Vienna Convention on Diplomatic Relations. ${ }^{82}$ Under Article 29 of the Convention, ${ }^{83}$ the person of the diplomatic agent shall be "inviolable" 84 and under Article 31 of the Convention, a diplomatic agent enjoys immunity from the criminal jurisdiction of the receiving state. ${ }^{85}$ At international law, this immunity could arguably be

80 Governor of Pitcairn v Sutton, above n 77, 436

81 Governor of Pitcairn v Sutton, above n 77, 433.

82 Diplomatic Privileges and Immunities Act 1968, s 5(1).

83 Imported into New Zealand law by s 5(1) of the Diplomatic Privileges and Immunities Act 1968.

84 Compare s 4(7)(d) of the Consular Privileges and Immunities Act 1971, in which immunity is only afforded to consular officers for crimes punishable with imprisonment for less than three years. This is more restrictive than the immunities afforded under the Vienna Convention on Consular Relations. Article 41(1) of that Convention provides that "Consular officers shall not be liable to arrest or detention pending trial, except in the case of a grave crime..."

85 The Diplomatic Privileges and Immunities Act 1968 contains a variety of situations in which immunities can be extended to international visitors. Under s 11 of the Act, if a Minister has doubts as to the extent to which immunities apply to representatives of Governments attending an international conference, the Minister of Foreign Affairs and Trade can direct that the privileges and immunities of a diplomatic agent under the Vienna Convention on Diplomatic Relations apply, via Gazette notice. This discretion can be used for foreign conference attendees at any level, including a Head of State. The person concerned would therefore be, prima facie, inviolable (see arts 29 and 31). Such a notice was gazetted for the September 1999 APEC Heads of Government conference in Auckland. The Governor-General may also make orders providing that members of international organisations are immune from suit. These orders can either extend the same immunities from suit and legal process as 
overridden by the jus cogens laws against torture or other crimes against humanity. The Convention's direct statutory effect in New Zealand would, however, render an application of that argument to the New Zealand legal framework problematic. It would require considerable judicial creativity to allow international norms to permeate a domestic legal term as categorical as "inviolable". An argument could be made that the Diplomatic Privileges Act is intended to incorporate New Zealand's international obligations on diplomatic privileges in their entirety, (that is, the Vienna Convention on Diplomatic Relations together with any applicable customary international law), and therefore that New Zealand should interpret its terms in accordance with the relevant international laws. ${ }^{86}$ This would involve an expansive application of the interpretative rule that domestic legislation should be construed consistently with international law.

\section{B Extraterritorial Prosecution for Crimes Against Humanity}

\section{Statutory extraterritorial offences}

New Zealand ratified the Torture Convention in 1986 and has fully implemented its obligations under the Crimes of Torture Act 1989. Section 3 of the Crimes of Torture Act 1989 gives the New Zealand courts universal jurisdiction for crimes of torture. Thus torturers present in New Zealand territory can be both prosecuted ${ }^{87}$ or extradited. ${ }^{88}$

a diplomatic agent (third Schedule) or immunity in respect of official functions only (fourth Schedule). See for example, (United Nations) Order 1959/51, (ILO) Order 1959/54, (South Pacific Commission) Order $1959 / 56$.

Under s 5(3) the Governor-General may declare that persons connected with a mission of a particular state have immunity from jurisdiction to give effect to a custom or agreement. See for example the Privileges and Immunities (Taipei Economic and Cultural Office) Order 1998 (SR 1998/339).

86 Lord Cooke's principle in Governor of Pitcairn $v$ Sutton, above n 77, 30, that a general statute should not be interpreted as being contrary to international law on an area such a sovereign immunity could be a starting point, but the principle would need to be significantly expanded. In that case the statute was of general effect. In contrast, in the situation outlined, the statutory provision is specific. Furthermore, the international legal principle that sitting Heads of State are liable for international crimes is less established than the general rule of sovereign immunity.

87 Crimes of Torture Act 1989, s 4(b).

88 Crimes of Torture Act 1989, s 8(1). 
Section 3 of the Geneva Conventions Act 1958 extends universal jurisdiction to the New Zealand courts for war crimes and crimes against humanity committed during armed conflict. 89

Dealing in slaves is the only other statutory crime against humanity for which the New Zealand courts have universal jurisdiction. ${ }^{90}$

\section{Non statutory crimes again st humanity}

New Zealand legislation on the face of it excludes the Courts from exercising universal jurisdiction for crimes against humanity through the common law. New Zealand criminal law has been fully codified since $1893,{ }^{91}$ and common law offences, including offences under customary international law, have been "abolished". ${ }^{92}$ Section 6 of the Crimes Act 1961 rules

89 These encompass crimes committed in the course of war in the form of unlawful and wanton wilful killing, torture or inhuman treatment including biological experiments, causing serious suffering or injury, extensive destruction and appropriation of property, compelling a prisoner of war or protected person to serve in the armed forces of the hostile power, depriving a prisoner of war the right to a fair trial, unlawful deportation, transfer or confinement of a protected person, taking of hostages, endangering the physical or mental health of a party. See also Gilbertson, above n 75, 553 .

90 Crimes Act 1961, s 98. There is no statutory offence of genocide in New Zealand. New Zealand ratified the Genocide Convention in 1978. However the Genocide Convention does not require states parties to set up universal domestic jurisdiction for genocide. Under the International War Crimes Tribunal's Act 1995, New Zealand can, in response to a request for assistance from the International Criminal Tribunal for the Former Yugoslavia, or the International Criminal Tribunal for Rwanda, arrest and surrender persons suspected of committing genocide in Rwanda or the former Yugoslavia. Section 13 of the Act makes provision for the Tribunal to sit in New Zealand, so extraterritorial acts of genocide can in fact be tried within New Zealand's territory, albeit under international jurisdiction. Other international crimes for which the New Zealand courts have universal jurisdiction are hostage taking (Crimes (Internationally Protected Persons, United Nations and Associated Personnel and Hostages) Act 1980, s 8), hijacking (Aviation Crimes Act 1972, s 3), endangering the safety of an international airport (Aviation Crimes Act 1972, s 5A) and piracy (Crimes Act 1961, s 92). See introductory footnote on subsequent law changes, $\uparrow$.

91 Maxwell and Bates Luxford's Police Law in New Zealand (4 ed, Butterworths, Wellington, 1991) 2.

92 Section 6 of the Criminal Code Act 1893 was the first provision precluding conviction under the common law. This was replaced by s 5 of the Crimes Act 1908. An explanatory note to s 5 stated its purpose was "to abolish common law offences." The current manifestation of this rule is s 9 of the Crimes Act, which says "no one shall be convicted of any offence at common law..." 
out extraterritorial prosecutions for statutory offences, unless such jurisdiction is expressly provided for. ${ }^{93}$

The effect of these provisions is to exclude from the jurisdiction of the New Zealand courts all extraterritorial crimes against humanity committed during peacetime, other than torture and slavery. Those crimes are widespread or systematic: murder, extermination, deportation or forcible transfer of population, imprisonment or other severe deprivation of physical liberty, grave sexual crimes, persecution on the grounds of political, racial, national, ethnic, cultural, religious or gender grounds, enforced disappearance, and apartheid. (See previous page for explanation.)

\section{Retrospective operation of statutory crimes}

The statutory extraterritorial crimes against humanity in New Zealand are prima facie precluded from operating retrospectively. The provisions concerned are neither expressly prospective or retrospective. However the retrospective operation of criminal legislation is statutorily barred. ${ }^{94}$ Section $10 \mathrm{~A}$ of the Crimes Act 1961 precludes liability in criminal proceedings "notwithstanding any other enactment or rule of law to the contrary" if the act in question did not constitute an "offence" at the time of commission. 95 "Offence" is defined as a statutory offence. ${ }^{96}$

The 1893 abolition of the common law as a source of New Zealand criminal law precludes the argument available in the United Kingdom that the statutory crimes against humanity

93 Section 6 of the Crimes Act provides "...no act done or committed outside New Zealand is an offence, unless it is an offence by virtue of any provision of this Act or any other enactment."

94 See Simester and Brookbanks Principles of Criminal Law (Brookers, Wellington, 1998) 23-24.

General legislation is also generally precluded from retrospective application under $\mathrm{s} 7$ of the Interpretation Act 1999

95 Section 10A says "notwithstanding any other enactment or rule of law to the contrary, no person shall be liable in any criminal proceedings in respect of an act or omission by him, if, at the time of the act or omission, the act or omission by him did not constitute an offence."

96 Section 2 defines offence as "any act or omission punishable under this Act or any other enactment". Similarly, s 26(1) of the Bill of Rights Act 1990 provides that "no-one shall be liable to conviction of any offence on account of any act or omission which did not constitute an offence by such person under the law of New Zealand at the time it occurred." For an application of s 26(1) see $R v$ King (1995) 3 HR NZ 425, 426 (HC) per Hammond J. 
codified pre-existing common law offences, as all the New Zealand provisions came into operation after 1893.

\section{Consent of the Attorney General required for prosecution of torture}

Under section 12(1) of the Crimes of Torture Act 1989, and section 3(5) of the Geneva Conventions Act 1958 no proceedings for the trial and punishment of any person can proceed 
in the absence of the consent of the Attorney-General. ${ }^{97}$ These provisions are is unusual but not unique. ${ }^{98}$ The Attorney General generally, "as a matter of convention and sound politics, keeps entirely out of [prosecution] decisions". 99 In the unusual cases where the Attorney General is required to consent to proceedings, in deciding whether to prosecute, the Attorney General must exercise in dependent judgment in the public interest, and not consult with his or her Cabinet colleagues. ${ }^{100}$

In the absence to date of any prosecutions under the Crimes of Torture Act, it is not possible to identify with any certainty the criteria the Attorney-General would apply in exercising the discretion to provide or withhold consent in respect of a particular prosecution. ${ }^{101}$ There is, however, case law which could suggest that a decision by the

97 These powers may be exercised by the Solicitor-General, see s 9A Constitution Act 1986. It is unclear whether the requirement for the Attorney-General's consent under the Crimes of Torture Act is intended to apply just to prosecution, or whether it extends to extradition. The wording of s 12(1) is general, in that it refers to the requirement for consent in "proceedings for the trial and punishment of any person charged with a crime described in ... s 3" and therefore might encompass extradition proceedings. However s 12(2) (providing that a person may be arrested and remanded in custody pending the consent of the Attorney-General) refers to the consent being for "institution of prosecution" which might suggest that the consent of the Attorney General is required for domestic prosecution only, as proceedings for extradition do not necessarily amount to an "institution of prosecution". If the latter were intended, then the legislature may not have anticipated that the political ramifications of an extradition can equal that of a domestic prosecution.

98 Other examples are ss 132 and 135 of the Human Rights Act 1993 (inciting racial disharmony and discriminatory denial of access to public places), and s 10A of the Crimes Act (prosecution after 10 years of the date of the offence).

99 GDS Taylor Judicial Review: a New Zealand Perspective (Butterworths, Wellington, 1991) 22; Grant Huscroft "The Attorney-General, the Bill of Rights, and the Public Interest" in Grant Huscroft and Paul Rishworth (eds) Rights and Freedoms: The New Zealand Bill of Rights Act 1990 and the Human Rights Act 1993 (Brookers, Wellington, 1995) 136.

100 Philip A Joseph Constitutional and Administrative Law in New Zealand (The Law Book Company Limited, Sydney, 1993) 260. Section 134 of the Criminal Justice Act 1988 (UK) also requires the AttorneyGeneral's consent in the prosecution for torture. In the UK, the Attorney-General is not a member of Cabinet. The British Attorney General was asked twice by Amnesty International to authorise Pinochet's prosecution in the early 1990's, but Pinochet left the country before the decision had been made. Since Pinochet's arrest in 1999, the Attorney-General has declined on several occasions requests by Amnesty International to prosecute domestically. Geoffrey Bindman "Lessons of Pinochet" (1999) 9 New Law Journal, 1050

101 For a discussion of the role of the Attorney General in prosecutions, see Huscroft and Rishworth, above n 99, 133-136 
Attorney-General not to proceed with a prosecution could be subject to judicial review if matters extraneous to the alleged offences weighed into the decision.

The case of Tavita $v$ Minister of Immigration ${ }^{102}$ considered the issue of whether the then Associate Minister of Immigration was required to consider the terms of the International Covenant on Civil and Political Rights and its Optional Protocol, and the Convention on the Rights of the Child, in making decisions as to the immigration status of the applicant. Although no final decision was taken by the Court, Crown Counsel's argument that the Minister and the New Zealand Immigration Service were entitled to ignore the international instruments was described by Cooke $\mathrm{P}$ as "unattractive". ${ }^{103}$ Later he said that: ${ }^{104}$

A failure to give practical effect to international instruments to which New Zealand is a part [sic] may attract criticism. Legitimate criticism could extend to the New Zealand Courts if they were to accept the argument that, because a domestic statute giving discretionary powers in general terms does not mention international human rights, norms, or obligations, the Executive is necessarily free to ignore them.

He went on to describe the judgment as "a case of possibly far reaching ramifications." 105

The subsequent cases of Puli'uvea v Removal Review Authority ${ }^{106}$ and Lawson v Housing New Zealand ${ }^{107}$ have confirmed that relevant international instruments (in both cases the ICCPR and the Convention on the Rights of the Child) should be taken into account when a statutory discretion is exercised. Those cases suggest, though, that consideration of the international principles may be sufficient discharge of the duty. ${ }^{108}$

The combined effect of these precedents is nevertheless, at a minimum, to render a decision by the Attorney-General to refuse consent to proceedings under the Crimes of Torture Act

102 Tavita $v$ Minister of Immigration (1993) 1 HRNZ, 30 (CA).

103 Tavita, above n 102, 40.

104 Tavita, above n 102, 41 .

105 Tavita, above n 102, 41.

106 Puli'uvea v Removal Review Authority (1996) 2 HRNZ 510 (CA).

107 Lawson v Housing New Zealand (1996) 3 HRNZ 285 (HC) per Williams J.

108 Puli'uvea, above n 106, 522 per Keith J. The case of Lawson v Housing New Zealand, above n 107, indicates that an attempt to balance relevant international instruments with competing considerations is sufficient discharge of the Tavita obligations. 
potentially susceptible to judicial review on the basis that insufficient regard was had to the provisions of the Torture Convention. It is arguable that the Torture Convention, being of a different nature to the conventions to which the Minister was to have regard in the cases to date, puts a higher onus of consideration on the Minister. Three reasons support such an approach. First, the preamble to the Crimes of Torture Act makes it clear that the Act is specifically designed to implement the provisions of the Torture Convention, so the Convention is of fundamental relevance to the statutory discretion. Secondly, the Torture Convention, unlike the Conventions relevant to the decisions to date, places concrete practical obligations on States Parties to either prosecute or extradite suspected torturers. Thus, failure to agree to prosecute such a person would be a direct and measurable breach of these obligations. Thirdly, and perhaps most importantly, the Torture Convention implements international norms of jus cogens nature, thus it has the highest status at international law and the ability to override other laws.

\section{Extradition Laws}

\section{Double criminality}

Section 4 of the Extradition Act 1999 defines "extradition offence" as "an offence punishable under the law of an extradition country for which the maximum penalty is imprisonment for not less than 12 months." In order to meet double criminality requirements, the conduct needs to have amounted to an offence "punishable under the law of New Zealand ... if it had occurred within the jurisdiction of New Zealand". 109

Unlike in the United Kingdom there is no ambiguity as to when the offence needs to have been criminal domestically: under section 4(3) the offence must be an offence at New Zealand law at the date of the offence, and not the date of the extradition request. ${ }^{110}$

\section{Extradition for statutory crimes against humanity}

Statutory crimes against humanity committed after the extraterritorial statutory offences came into force would meet the definition of extradition crimes under the Extradition Act

109 Extradition Act 1999, s 4(2).

110 Under s 4(3) extradition offences must meet the following condition. "...if the conduct of the person constituting the offence in relation to the extradition country, or equivalent conduct, had occurred within the jurisdiction of New Zealand at the relevant time it would, if proved, have constituted an offence punishable under the law of New Zealand for which the maximum penalty is imprisonment for not less than 12 months or any more severe penalty." 
1999.111 Thus persons suspected of such crimes could be extradited to third states en deavouring to exercise universal jurisdiction against a non-national.

Extradition for crimes that predated the statutory extraterritorial jurisdiction would not be possible, in light of the statutory scheme discussed above, which precludes the retrospective operation of criminal statutes.

\section{Extradition for non statutory crimes against humanity}

The requirement under section 4(1)(b) of the Extradition Act 1999 for the offence subject to the extradition request to be punishable "under the law of New Zealand" creates problems for the extradition of persons charged with non statutory crimes against humanity when universal jurisdiction is being exercised. This is because, as discussed above, under the law of New Zealand, only statutory crimes are punishable. Double criminality would therefore not exist for extradition requests relating to extraterritorial crimes against humanity not codified under New Zealand legislation.

There is, however, some basis for arguing, consistent with the obligatio erga omnes principle, that the New Zealand courts have the power to extradite for all crimes against humanity, including where the requesting state is seeking to prosecute extraterritorially. This relates to the section 4(2) requirement for the "conduct of the person" or "equivalent conduct" to have constituted an offence if it "had occurred within the jurisdiction of New Zealand" (emphasis added), and applies the principle that legislative ambiguities are to be resolved in favour of international principles. It is arguable that in section 4(2), "jurisdiction of New Zealand" means the territory of New Zealand, as opposed to the scope of jurisdictional reach of New Zealand courts. ${ }^{12}$ Under that approach, the jurisdictional basis for the crime would be irrelevant. ${ }^{113}$

111 The maximum penalty for torture, slavery, and war crimes or crimes against humanity in armed conflict is 14 years: Crimes of Torture Act 1989, s 3 (torture); Crimes Act 1961, s 98 (slavery); Geneva Conventions Act 1958, s 4(a) and 4(b) (war crimes).

112 See Oxford Dictionary of Law (4 ed, Oxford University Press, Oxford, 1997) 253 which has three definitions of jurisdiction: "1. The power of a court to hear and decide a case or make a certain order. 2. The territorial limits within which the jurisdiction of a court may be exercised. In the case of English courts this comprises England, Wales, Berwick upon Tweed, and those parts of the sea claimed as territorial waters. Everywhere else is said to be outside the jurisdiction. 3. The territorial scope of the legislative competence of Parliament."

113 See Grainne Mullan "The Concept of Double Criminality in the Context of Extraterritorial Crimes" [1997] Crim L R 17, 21. 
The only question would be whether the acts are an offence against New Zealand law with a maximum penalty of at least 12 months. Thus, New Zealand could potentially extradite an alleged offender when the requesting state was exercising universal jurisdiction for a crime against humanity, as there are legislative provisions under which crimes against humanity, committed intraterritorially, could be prosecuted. ${ }^{114}$

\section{Conclusion}

The abolition of the common law as a source of New Zealand criminal law means that there are significant impediments to the prosecution and extradition for non-statutory extraterritorial crimes committed during peace.

In order for New Zealand to be in a position to meet its evolving international responsibilities to prosecute and extradite perpetrators of crimes against humanity within its territory, a legislative review is therefore required. The following law changes are suggested:

(1) The replacement of the Crimes of Torture Act with a "Crimes Against Humanity Act", creating, with express retrospective effect, universal jurisdiction for all crimes against humanity. ${ }^{115}$

(2) An amendment to the Diplomatic Privileges and Immunities Act 1968 rendering the immunities of diplomats subject to customary international laws on international criminal responsibility, to bring their immunities in line with New Zealand common law on Head of State immunity.

114 Thus if, for example a request was received from the Netherlands for New Zealand to extradite to its courts a Cambodian national present in New Zealand who was suspected of widespread and systematic murder of Khmers, and the offence against Dutch law was one of extraterritorial extermination, the territorial basis of the Dutch request would be irrelevant. The only matter that would need to be considered was whether the acts, if committed within New Zealand had the requisite criminality. It would not be necessary to prove that the New Zealand courts could have the jurisdictional reach to try the offence extraterritorially. Murder is a crime in New Zealand with a mandatory life penalty (Crimes Act 1961, s 167). Other crimes against humanity could be caught by multiple charges under provisions such as assault (Crimes Act 1961, ss 188-204), homicide (ss 158-166), sexual crimes (ss 127-144), or conspiring to commit such offences (s 310). See introductory footnote on subsequent law changes, $\uparrow$.

115 Crimes against humanity could be defined as a non-exhaustive list to enable international advances in the definition of the offence to be reflected domestically without the need for subsequent law change. See introd uctory footnote on subsequent law changes, $\dagger$. 


\section{THE FUTURE}

A perusal through a human rights yearbook illustrates the global scale of human rights abuses. Numerous countries, every year, are complicit in systematic atrocities that could amount to crimes against humanity. These include torture, imprisonment of political opponents, enforced disappearance, rape, and forcible transfer of population. ${ }^{116}$

The effect of the Pinochet judgment should therefore not be underestimated. It is clear authority for the proposition that former Heads of State cannot claim immunity in municipal courts outside their home country for acts of torture performed while in office. The judgment also suggests that immunity would be unavailable for other crimes against humanity. The same reasoning could potentially be applied to sitting Heads of State.

Lord Millet's judgment in particular could have profound ramifications. He asserts that there has been universal jurisdiction for crimes against humanity since the time of the Nuremberg Tribunal, and that all jus cogens crimes would be punishable by municipal courts. On that basis any former Heads of State or State agents who have committed crimes against humanity in the second half of this century could find themselves facing proceedings before domestic courts of foreign states.

The judgment appears already to have dramatically altered the political landscape for abusers. Former Indonesian President Suharto has reportedly been advised by his lawyers not to travel overseas. ${ }^{117}$ A few months after the judgment, Saddam Hussein's former deputy departed suddenly from Austria after a politician sought his arrest for torture and genocide. ${ }^{118}$ In February 2000, the former dictator of Chad was arrested in Senegal for crimes against humanity. ${ }^{119}$ Perhaps most importantly, the revocation of British proceedings against Pinochet

116 For example The Amnesty International Report 1999 (Amnesty International Publications, London, 1999) reports widespread torture and detention of political opponents in China (127), Iraq (202), Myanmar (256), India (191) widespread torture in Pakistan resulting in at least 50 deaths (256), systematic killings of thousands in Afghanistan (70); widespread killings in Algeria (73); widespread torture including rape in custody in Bangladesh (90) and so on.

117 "Suharto Fears the Pinochet Effect" The Independent, London, 22 August 1999.

118 "Iraqi Official Flees Austria: Alleged Role in Kurd Slayings Spurs Criminal Complaint" The Washington Post, United States, 19 August 1999, A18; "How to Get Away With Murder" Independent, London, 22 August 1999.

119 "Human Rights Breakthrough as African Ex-Dictator is Indicted" The Guardian, London, 4 February 2000. 
on medical grounds on 2 March 2000 by no means signalled an end to his proceedings against him. He has been stripped of his congressional immunity and is currently facing more than 250 law suits in Chile. ${ }^{120}$

Three key messages therefore emerge from an assessment of the Pinochet decision.

The first is for law makers. It is critical to create a robust domestic legal regime that allows for the punishment of international criminals.

The second is for judges and practitioners. In cases of ambiguity, or legislative gap, a number of international legal principles should be invoked to ensure international criminals do not go unpunished.

The third and most important message is to Heads of State who brutalise their citizens. The international community will no longer tolerate these crimes.

120 "Pinochet Opponents Celebrate Court Ruling" The Guardian, London, 6 June 2000. 